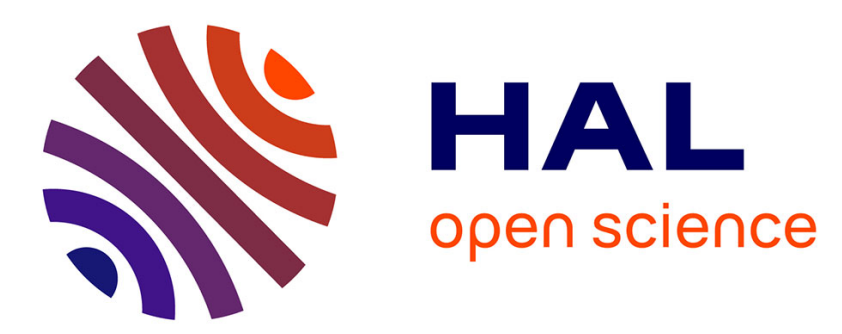

\title{
Do Asymmetric Information and Ownership Structure Matter for Dividend Payout Decisions? Evidence from European Banks
}

Laetitia Lepetit, Céline Meslier-Crouzille, Leo Indra Wardhana

\section{- To cite this version:}

Laetitia Lepetit, Céline Meslier-Crouzille, Leo Indra Wardhana. Do Asymmetric Information and Ownership Structure Matter for Dividend Payout Decisions? Evidence from European Banks. 2015. hal-01186722

\section{HAL Id: hal-01186722 \\ https://hal-unilim.archives-ouvertes.fr/hal-01186722}

Preprint submitted on 25 Aug 2015

HAL is a multi-disciplinary open access archive for the deposit and dissemination of scientific research documents, whether they are published or not. The documents may come from teaching and research institutions in France or abroad, or from public or private research centers.
L'archive ouverte pluridisciplinaire HAL, est destinée au dépôt et à la diffusion de documents scientifiques de niveau recherche, publiés ou non, émanant des établissements d'enseignement et de recherche français ou étrangers, des laboratoires publics ou privés. 


\title{
Do asymmetric information and ownership structure matter for dividend payout decisions? Evidence from European banks
}

\author{
Laetitia Lepetit $^{\mathrm{a}}$, Celine Meslier ${ }^{\mathrm{a}}$ and Leo Indra Wardhana ${ }^{\mathrm{a}}$ \\ ${ }^{a}$ Université de Limoges, LAPE, 5 rue Félix Eboué, 87031 Limoges Cedex, France
}

August 13, 2015

\begin{abstract}
We empirically examine whether banks' dividend decisions are influenced by their degree of opacity and ownership structure. We find that banks with concentrated or dispersed ownership structure pay lower dividends when they have high degrees of opacity. These results would be consistent with the entrenchment behavior hypothesis, with insiders (managers or majority shareholders) paying lower dividends to extract higher levels of private benefits when banks' opacity is high. Higher levels of shareholder protection and stronger supervisory regimes help to constrain entrenchment behavior of majority shareholders. Our findings have critical policy implications for the Basel 3 implementation of restrictions on dividend payouts.
\end{abstract}

JEL Classification: G21, G28, G35

Keywords: Bank, dividend, ownership concentration, asymmetric information

E-mail addresses: laetitia.lepetit@unilim.fr (L. Lepetit), celine.meslier@unilim.fr (C. Meslier) and leoindra.wardhana@etu.unilim.fr (L. Wardhana). 


\section{Introduction}

Dividend policy has been an area of intense research in corporate finance, with theoretical and empirical analysis showing that firms follow well considered payout strategies (e.g. Fama and French 2001, Banerjee et al. 2007). Within this literature, the role of dividend policy dealing with asymmetric information and agency conflicts between corporate insiders and outsiders has received a great deal of attention. The payment of dividends decreases the level of funds available for perquisite consumption and investment opportunities and requires insiders to seek financing in capital markets. Dividend payouts can therefore be used as a control mechanism by outside shareholders to prevent entrenchment or empire-building (e.g. Easterbrook 1984, Jensen and Meckling 1976, and Zwiebel 1996).

While there is an extensive literature analyzing whether dividend policy is used as a corporate mechanism to reduce agency conflict in the case of non-financial firms, few empirical papers analyze this issue for financial firms, despite its regulatory relevance. This issue is of particular interest because the distribution of earnings as dividends obviously reduces banks' ability to generate capital internally, and then transfers default risk to their creditors and deposit insurer (Acharya et al. 2009, 2013). Moreover, banks distributed large scale dividend payouts during the 2007-2008 financial crisis despite widely unanticipated losses, shedding light on the severe malfunctioning of banks corporate governance mechanisms. In this context, the objective of this paper is to empirically examine whether dividend payments are used by banks' insiders as a corporate mechanism, allowing for different agency conflicts and different levels of asymmetric information.

As pointed out in La Porta et al. (1998), the level of ownership concentration is a key determinant of the nature of agency conflicts between the different firm stakeholders. In the U.S., the United-Kingdom, Canada and Australia where the ownership is dispersed, the main corporate governance problem is the misalignment of shareholders' and managers' interests. When the ownership is concentrated, as is prevalent in continental Europe and Asia, the conflict of interest shifts away from manager vs. shareholders to majority vs. minority shareholders, as large shareholders have incentives to maximize their own benefits at the cost of other shareholders (Shleifer and Vishny 1997). In both cases, dividend payouts can be used to create shareholder value by reducing free cash flow that can be spent by insiders (managers or majority 
shareholders) on value-decreasing projects (Lang and Litzenberger 1989, Chae et al 2009). Higher dividend payouts can then signal that insiders will refrain from expropriation (signaling behavior). Such signaling behavior can be of importance as the potential expropriation of outside investors can be costly to insiders in terms of higher equity financing costs (e.g. Chen et al. 2009, Chu et al. 2014) and lower firm valuation and returns (e.g. Claessens et al. 2002, Lins 2003, Lemmon and Lins 2003). On the other hand, insiders might have incentives to only pay small dividends in order to increase the amount of free cash flow they can divert for their private consumption (entrenchment behavior) (Gomes 2000). The intensity of the agency conflict between insiders and outsiders may be stronger in the presence of concentrated ownership (Davies 2000, Sáez and Riaño 2013). Indeed, in dispersed ownership, different corporate governance mechanisms can be put into place to give top managers strong incentives to discourage entrenchment behaviors, such as, compensation mechanism, dismissal threats or the threat of a hostile takeover. These different corporate mechanisms aiming to rein in managers' behavior are much less relevant when the ownership structure is concentrated, as large investors can elect their representative(s) to the board of directors who will appoint a manager that will act in the interest of these controlling shareholders.

The empirical literature analysing the effectiveness of dividend policy to reduce agency conflicts when there is dispersed ownership structure provides mixed results. Some studies on non-financial firms find that dividends are used by managers to communicate information to shareholders when there is a conflict of interest (e.g. Healy and Palepu 1988, Denis et al. 1994, and Yoon and Starks 1995), whereas other studies do not observe evidence that dividends are used as a signaling device (e.g. Benartzi et al. 1997, and Li and Zhao 2008). Empirical studies dedicated to the banking industry, mostly on U.S. bank holding companies, find evidence that dividends are used as a signaling mechanism (Filbeck and Mullineaux 1993, Bessler and Nohel 1996, Filbeck and Mullineaux 1999, Dickens et al. 2002, Theis and Dutta 2009, and Abreu and Gulamhussen 2013). In contrast, Galiakhmetova et al. (2015) find, for a sample a European listed banks, a negative relationship between CEO power and dividend payments, indicating that entrenched CEOs do not have incentives to increase payout ratios to discourage monitoring from minority shareholders. 
Even if the intensity of the agency conflict may be stronger when insiders are controlling shareholders (instead of managers), the empirical literature analyzing the impact of a concentrated ownership on dividend policy is scarcer and provides mixed results. Bøhren et al. (2012) and De Cesari (2012) find that higher dividends are paid in non-financial firms when the agency conflict between large and small owners is stronger, consistent with signaling behavior. However, Faccio et al. (2001) and Gugler and Yurtoglu (2003) find that dividends are higher in non-financial firms with the presence of multiple large shareholders; the other large shareholders impede the controlling shareholder's expropriation of minority shareholders. La Porta et al. (2000) further find that this happens only to firms located in countries with better protection of minority shareholders, as asset diversion is legally riskier and more expensive in such countries, thereby raising the relative incentives of large shareholders to grant dividends to minority shareholders.

Despite the importance of the degree of asymmetric information faced by outsiders to explain the intensity of the agency conflict with either managers or majority shareholders, only few studies examine the relationship between the level of asymmetric information and dividend policy. The empirical results on the effects of asymmetric information on dividends are mixed, focusing only on listed non-financial firms which have generally a dispersed ownership structure. While Li and Zhao (2008) and Leary and Michaely (2011) find that U.S. firms with higher levels of asymmetric information distribute lower dividends, Von Eije and Meggison (2008) find in contrast that European firms with higher asymmetric information pay higher dividends. Brockman and Unlu (2011) further find a U-shaped relationship between dividend payments and disclosure quality.

Our paper complement the existing literature by exploring further the linkages between asymmetry of information, corporate governance and dividend payout decisions for the banking industry. We examine if agency conflicts between stakeholders influence banks' dividend policy differently depending on the level of asymmetric information faced by stakeholders and the ownership structure (dispersed vs. concentrated). We use for that a panel of listed and non-listed European commercial banks over the 2004-2012 period, with heterogeneity in term of agency conflicts. While the influence of asymmetric information on dividend payouts is of particular importance for banks as their financial structure combined with high leverage makes them inherently more 
opaque than other firms (Morgan 2002), this aspect has not been explicitly taken into account in existing studies. Whether the dividend policy can help to alleviate agency problems between insiders and outsiders is not a clear cut issue when outsiders are confronted with a high level of asymmetric information. One could argue that in the presence of high opacity, it might be much easier for insiders, both managers and majority shareholders, to extract private benefits of their control. In the presence of such entrenchment behavior, we could then expect a stronger contraction of dividends as the level of opacity increases. However, if insiders want to signal to outsiders that they will not be expropriated, we expect banks to distribute higher dividends with dividends increasing with the level of opacity faced by investors. We test if these two alternative hypotheses of entrenchment or signaling behavior depend on who is involved in managerial decisions, i.e. managers in a dispersed ownership structure and majority shareholders in a more concentrated ownership. We further examine if the institutional and regulatory environment, more specifically the level of shareholder protection and supervisory actions, can constrain any opportunistic entrenchment behavior. Our period of investigation also allows us to determine whether banks' payout behavior is different in normal times and during the financial crisis period.

We find that European banks with either a concentrated or a dispersed ownership structure pay lower dividends when they present high degrees of opacity. These results would be consistent with the entrenchment behavior for banks, with insiders (either managers or majority shareholders) paying lower dividends to extract higher levels of private benefits when outsiders face higher degrees of asymmetric information as it might be more difficult to detect such opportunistic behavior. We find that this entrenchment behavior is observed before and during the crisis period; higher levels of shareholder protection help to constrain it but only when insiders are majority shareholders, whereas stronger supervisory regimes contribute to moderate the entrenchment behavior of both managers and majority shareholders.

Our paper makes several contributions to the existing literature. We contribute to the literature exploring the determinants of dividend policy by analyzing if the levels of asymmetric information combined with different ownership structures influence the dividend payout policy. We also add to the literature investigating the dividend payout decisions of banks. Few empirical papers analyze the determinants of dividend policy of banks, while the Federal Reserve Board (FRB 2011) and the Basel Committee on 
Banking Supervision (BCBS 2011) have been emphasizing the necessity to increase oversight of banks' dividend payouts. Indeed, as pointed out by Abreu and Gulamhussen (2013), while imposing constraints on bank dividend payments may reduce equity-debt agency conflicts and avoid wealth transfer from debt to equityholders, it may also reduce the ability of banks to signal their future growth perspectives to investors. We also highlight that such constraints on dividend payments might facilitate insiders' entrenchment behavior when stakeholders face high levels of asymmetric information. By analyzing the relationship between the degree of opacity and dividend payouts for different levels of ownership concentration, using detailed bank level data especially on their ownership structure, and examining a wider dataset containing both listed and unlisted banks, we further aim to obtain a better understanding of the underlying mechanisms at work. For this we focus on a European dataset which provides a substantial amount of variability between individual levels of ownership concentration given the lack of regulatory limitations on the percentage of bank capital owned by a single entity in Europe.

Section 2 describes our sample, the ownership characterization and the measures of opacity used. Section 3 presents our methodology. Section 4 discusses our main results. Section 5 tests the robustness of those results and Section 6 concludes the paper.

\section{Data and variable construction}

\subsection{Sample}

Our sample covers listed and non-listed commercial banks from 15 European countries (Austria, Belgium, Denmark, Finland, France, Germany, Greece, Ireland, Italy, Luxembourg, the Netherlands, Portugal, Spain, Sweden and the United Kingdom). Our data set covers the period 2004-2012. We extracted bank financial statement data from BvD Bankscope. We consider consolidated data but also use unconsolidated data when consolidated balance sheets are not available. All the banks in our sample publish their annual financial statements at the end of the calendar year. As for the ownership structure of banks, we compute time-varying variables by combining data from several sources, i.e. BvD Bankscope, Thomson Reuters Advanced Analytics and handcollected annual reports, in order to obtain information as complete as possible.

BvD Bankscope provides financial statement data for 1,062 active European commercial banks for at least some of the period considered. We limit our sample to 
European commercial banks which provide information on our variables of interest and we clean the data by dropping the lowest and highest $1 \%$ observations. We further apply specific cleaning criteria for the variable measuring the dividend payout ratio, defined as total dividends paid related to the period divided by net income. ${ }^{1}$ We check if there are banks that have non-positive earnings but still pay dividends. We find 96 observations for which banks have negative earnings, with 42 among them that pay dividends. ${ }^{2}$ We also have 16 observations for which banks have zero earnings, with 4 that still pay dividends. We drop the 46 observations in our data cleaning corresponding to banks with non-positive earnings which pay dividends, to avoid negative dividends and infinite numbers.

We end up with a final sample of 1,150 annual observations corresponding to 330 European commercial banks (see Table 1 for a breakdown by country). Table 2 presents some general descriptive statistics for both our data set and the corresponding full sample of banks available under BvD Bankscope. The median data coverage of our sample, as measured in percent of total assets in the wider BvD Bankscope one, lies at almost $54 \%$, with very similar bank activity characteristics between the two (see Table $1)$.

[Insert Tables 1 and 2 here]

\subsection{Ownership measures}

To classify banks according to the level of concentration of their ownership structure, we follow Bouvatier et al. (2014) and use a hierarchical agglomerative clustering (HAC) approach to account more accurately for several dimensions of banks' ownership characteristics. Three ownership measures are considered to identify banks which have similar characteristics in the construction of different clusters: the

\footnotetext{
${ }^{1}$ We do not include preferred dividends because we argue that unlike common dividends, payouts for preferred stocks are hardly similar to common dividend payout decisions where the payout is fixed. Thus, the controlling shareholder cannot influence the decision of preferred dividend payments. The only decision that could be influenced is whether to issue preferred stocks or not in the first place. Consequently, for example, assuming that most of preferred stocks are cumulative, the controlling shareholder may be able to expropriate the other shareholders by not paying dividends, but they cannot do it to preferred shareholders. There are only 21 observations in our sample that have share repurchase. Including share repurchase do not change our results.

${ }^{2}$ We have 21 banks that paid dividends while having negative earnings during the financial crisis of 2007-2008 (among them Royal Bank of Scotland, Loyds Bank and Credit Agricole), while only 3 banks paid dividends with negative earnings before 2007 .
} 
percentage of shares held by the largest shareholder $\left(\right.$ Share $\left._{i j, t}\right)$, the percentage of shares held by the second-largest shareholder $\left(\operatorname{Share} 2_{i j, t}\right),{ }^{3}$ and the Herfindahl-Hirschman index $\left(\right.$ Concentration $\left._{i j}\right) .{ }^{4}$ The first two measures give information on the presence of one or two large shareholders, and the Herfindahl index captures the concentration of the ownership. The HAC uses Euclidean distance to compute similarity between two banks. The Ward method is used to determine the distance between clusters consisting of several banks (see Appendix A in Bouvatier et al. 2014 for more details). We obtain three distinct bank clusters, labelled Cluster 1, 2 and 3. Banks can change cluster over time if their ownership structure changes accordingly. 89 banks belong to Cluster 1, 119 banks to Cluster 2 and 187 to Cluster 3 at some point in time amongst the 330 banks in our sample, with 65 banks that change between clusters during the sample period. General descriptive statistics for banks in these clusters are provided in Table 2, and Table 3 provides statistics for the ownership measures for each of the three clusters.

With the largest and the second largest shareholder holding on average respectively $15.71 \%$ and $10.45 \%$ of the shares, banks in Cluster 1 (dispersed ownership) are characterized by a dispersed ownership structure with a large number of shareholders that do not hold controlling shares (see Table 3). We assume that the conflict of interest between managers and shareholders is highest in this cluster as there is a separation between ownership and control. Banks in Cluster 2 (concentrated ownership) have a concentrated ownership structure with either one shareholder or two shareholders that hold a controlling stake (for a control threshold of 50\%), and some smaller shareholders. Banks in Cluster 3 (highly concentrated ownership) display a very strong level of ownership concentration. The controlling shareholder holds on average around $98.5 \%$ of the shares, with other shareholders holding a corresponding small percentage. Hence, in Clusters 2 and 3, the conflict of interest is between majority and minority owners.

\footnotetext{
${ }^{3}$ We alternatively use the ratio of the shares held by the second largest shareholder to those held by the largest shareholder $\left(\right.$ Share $_{i j, t} /$ Share $\left._{i j, t}\right)$ instead of Share $2_{i j, t}$ to construct our clusters. This ratio measures the relative power of the second largest shareholder compared to the largest shareholder, with the highest value implying comparable size between the controlling stakes of the two largest shareholders. The classification of banks are very similar when we use either (Share2/Share1) or Share2.

${ }^{4}$ We compute for each bank $i$ the variable $O S_{i}$, defined by the ratio of the percentage of equity held by each shareholder $n$ to the total percentage of equity held by all shareholders; we then compute Concentration as $\sum_{n=1}^{N} O S_{n}^{2}$ with $N$ the total number of shareholders. The higher the Herfindahl index, the higher the concentration of bank ownership.
} 
We build on this classification to construct our ownership structure variables. We compute the dummy variables $C k_{i, t}$ that takes the value of one if the bank $i$ is in Cluster $k$ for the year $t$ and zero otherwise, with $k=\{1,2,3\}$.

[Insert Table 3 here]

\subsection{Opacity measures}

We define opacity as information asymmetry between more or less informed stakeholders. We build on the existing literature to compute a composite index based on proxies that capture four components of opacity.

Our first information asymmetry component $\left(E F_{i j, t}\right)$ measures the disconnection between insiders' and outsiders' information about firms' financial condition. A firm's information opacity is expected to affect the properties of financial analysts' forecasts, with higher analyst earnings forecast error and dispersion in analyst forecasts (e.g., Krishnaswani and Subramaniam 1999, Diether et al. 2002). We build an earnings prediction model based on publicly available information and use the residual of the regression as a measure of insiders' private information, following Park (1999) and Crouzille et al. (2004) (see Appendix 2 for more details). The higher the forecast error $E F_{i j, t}$, the higher is the opacity.

Our second information asymmetry component $\left(E M_{i j, t}\right)$ is related to the opacity of financial statements. A decrease in the quality of financial statements is likely to widen the asymmetric information about firm financial position between insiders and outsiders. Since Dechow and Dichev (2002), the accepted view is that insiders' discretion influences accrual quality and reduces the information that outside investors can collect from financial statements. Moreover, insiders can hide their self-serving behaviors through earnings management (e.g. Leuz et al. 2003, Cornett et al. 2009, Bouvatier et al. 2014). Accounting numbers no longer reflect the economic reality of underlying risk conditions in this case and it is difficult for outsiders to accurately assess the fundamental value of the bank. We follow Hutton et al. (2009) and Lang and Maffett (2011) and use the degree of earnings management as a measure of accounting opacity. Previous studies regarding earnings management at banks measure it via loan loss provisions because these are relatively large accruals and therefore have a significant 
impact on banks' earnings (Ahmed et al. 1999). ${ }^{5}$ We use a similar approach to Bouvatier and Lepetit (2008) to measure the discretionary element of loan loss provisions that are used for earnings management (see Appendix 2 for more details). The higher the earnings management $E M_{i j, t}$, the higher is the opacity.

Our third information asymmetry component is the negative of the ratio of short term and long term market funding to total assets $\left(M F_{i j, t}\right)$, which shows the degree of banks' exposure to the market. When banks have greater exposure to the market, there will be more market participants to assess the fair value of the bank, thus reducing asymmetric information. The proportion of market funding on the liability side of the balance-sheet is considered as a signal for outsiders of lower opacity (Crouzille et al. 2004). The higher $M F_{i j, t}$ (lower market funding), the higher is the opacity.

Our last information asymmetry component is the proportion of loans in total assets $\left(\operatorname{Loan}_{i j, t}\right)$. Theoretical analyses all lead to the same conclusion that bank loans are opaque (e.g., Campbell and Kracaw 1980, Berlin and Loeys 1988, Diamond 1991). These theories show that bank loans are unusually difficult for outside investors to value as insiders have privileged information about the characteristics of the loan contracts and the creditworthiness of the borrowers. ${ }^{6}$ The higher the loan proportion, the higher is the opacity.

We use the four variables $E F_{i j, t}, E M_{i j, t}, M F_{i j, t}$, and $L_{o a n} n_{i j, t}$ to construct our opacity composite index $\left(\right.$ Opacity $\left._{i j, t}\right)$. We check that the four components of our composite index capture different dimensions of information asymmetry. The low correlations among the variables $E F_{i j, t}, E M_{i j, t}, M F_{i j, t}$ and $\operatorname{Loan}_{i j, t}$ show that this is the case (see Table A1 in Appendix 1). We associate the four components $E F_{i j, t}, E M_{i j, t}, M F_{i j, t}$ and $\operatorname{Loan}_{i j, t,}$ with the value of one for the first decile, the value of two for the second decile and so on. We then sum these four proxies and we divide it by four to scale our composite

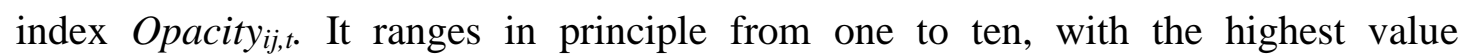
representing the highest level of opacity that outsiders can face. This index provides a

\footnotetext{
${ }^{5}$ Earnings management could also be measured by discretionary realizations of security gain or losses (Cornett et al. 2009). However, the net gain on securities only represents around $4 \%$ of the total operating income in our sample for European commercial banks, leaving little scope for earnings management.

${ }^{6}$ Trading assets also represent an important source of opacity for banks (Morgan 2002). However, in our sample, trading assets are concentrated primarily at the largest banks. On average, less than 1.14 percent of assets are held as trading assets, whereas loans represent on average around 56 percent of the total assets and are therefore the primary assets for most banks.
} 
robust measure of opacity because it averages across several measures of asymmetric information. For our sample of European commercial banks, the index has a mean of 5.62 and ranges from 2.25 to 9.25 (see Table 4). The opacity composite index is significantly higher in Cluster 2 compared to Cluster 3, but not compared to Cluster 1.7 We compute the dummy variable High Opacity $_{i j, t}$, that takes the value of one if the index Opacity $_{i j, t}$ of a bank is greater than the sample median value and zero otherwise, to differentiate banks which have a relatively high and low degree of opacity.

[Insert Table 4 here]

\section{Specifications and hypotheses tested}

\subsection{Baseline specification}

We first investigate whether the decision of insiders to pay dividends depends on the interconnection between the degree of opacity faced by outsiders and the level of ownership concentration. For that, we estimate the following equation

$$
\begin{gathered}
D P_{i j, t}=\sum_{\mathrm{k}=1}^{3} \gamma_{k} C k_{i j, t}+\sum_{k=1}^{3} \delta_{k} C k_{i j, t} * \text { High Opacity }_{i j, t} \\
+\sum_{\mathrm{k}=1}^{10} \beta_{k} \text { Controls }_{i j, t}+\alpha_{t}+\varepsilon_{i j, t}
\end{gathered}
$$

where $i, j, t$ stand respectively for bank, country and time.

The dividend payout $\left(D P_{i j, t}\right)$ is defined as total dividends paid related to the period divided by net income. The dividend to earnings ratio is the most commonly used measure of dividend payouts as it captures the key element of the payout policy (La Porta et al. 2000, Fidrmuc and Jacob 2010). We include the three cluster dummy variables altogether instead of considering a reference category (we then drop the constant). We also include interaction terms between the Cluster dummy variables $C k_{i j, t}$ and the dummy variable High Opacity $_{i j, t .}$. The dividend payouts of banks in Cluster $k$ with a low degree of opacity is given by $\left(\gamma_{k}\right)$, while those of banks with a relatively high degree of opacity is given by $\left(\gamma_{k}+\delta_{k}\right)$.

We test two alternative hypotheses. If insiders signal their unwillingness to extract private benefits when the opacity is relatively high by granting dividends to outsiders

\footnotetext{
${ }^{7}$ Mean tests are available on request.
} 
(signaling hypothesis), we expect $\delta_{k}$ to be significantly positive. If alternatively insiders decide to decrease dividends as it increases the funds at their discretion when the opacity is relatively high (entrenchment hypothesis), we expect $\delta_{k}$ to be significantly negative. We further test if, for the same degree of opacity, the dividend payout ratio is increasing or decreasing with the level of ownership concentration. If we follow Davies (2000) and Sáez and Riaño (2013), we would expect that agency conflicts are stronger in concentrated ownership than in dispersed ownership. We would then observe either an increase of dividends between clusters if insiders in a more concentrated ownership want to signal their unwillingness to expropriate outsiders, or on the contrary, a decrease of dividends if they use their controlling power to increase funds they have at their discretion.

We build on the existing literature and include control variables that might have an impact on the dividend policy of firms. Size, profitability and growth opportunities are important determinants of dividend payout ratios of non-financial firms (e.g. La Porta et al. 2000, Fama and French 2001, and Von Eije and Megginson 2008). We measure bank size $\left(\right.$ Size $\left._{i j, t}\right)$ through the natural logarithm of total assets and use the return on asset $\left(R O A_{i j, t}\right)$ to measure the profitability. We expect large and more profitable banks to pay higher dividends. In order to measure investment opportunities, we use the growth rate of total assets (Assets Growth ${ }_{i j, t}$ ) to measure investment opportunities of banks. Banks with high growth opportunities are expected to plowback their earnings to avoid costly equity and debt financing. We further include the dummy variable $M \& A_{i j, t}$ that identifies banks which were involved in operations of acquisition during our period of analysis, as the dividend policy should be reviewed to reflect the dividend policy of the combined entity and satisfy both acquirer and target firm shareholders. ${ }^{8}$ We also control for macroeconomic condition differences across countries by including the GDP growth rate (GDP growth $\left._{j, t}\right)$.

The banking literature suggests that other variables might have an impact on banks' dividend payouts. Onali (2014) finds that banks having higher default risk have higher payout ratios. We use a time-varying Z-score based on 3-year rolling windows to proxy

\footnotetext{
${ }^{8}$ We use the database Thomson Reuters Advanced Analytics to identify mergers and acquisitions involving European commercial banks.
} 
bank default risk. ${ }^{9}$ We follow Lepetit and Strobel (2015) and use its natural logarithm in our specifications (Ln Zscore $i j, t)$. Acharya et al. (2011) show that the optimal dividend policy also depends on the bank's franchise value. In line with this theoretical finding, Onali (2014) shows that the bank charter value has a negative impact on dividend payouts. Banks with higher charter have an incentive to pay lower dividends in order to preserve the charter. We use the ratio customer deposits to total assets (Deposit $\left.{ }_{i j, t}\right)$ to proxy the charter value based on the banking literature showing that customer deposits contribute to a bank's charter value (e.g. James 1991, Goyal 2005). We compute the dummy variable High Charter $_{i j, t}$ that takes the value one if the ratio customer deposits to total assets is larger than the sample median, and zero otherwise. We further control for the level of capitalization by introducing the dummy variable High Capitalized ${ }_{i j, t}$ that takes the value of one if the previous year's risk-weighted capital ratio is larger than the sample median, and zero otherwise. Banks with lower regulatory capital ratios are expected to have lower dividend payouts than well-capitalized banks, as dividends paid affect the ability of banks to build a solid capital buffer (Acharya et al. 2011, Onali 2014). As our period of analysis includes the financial crisis period of 2007-2008, we also control for banks that were in distress during this period by including the dummy variable Distress $i j, t$ equal to one if a bank was in distress, and zero otherwise. ${ }^{10} \mathrm{We}$ expect these banks to distribute fewer dividends due to financial constraints.

Finally, we consider an index measuring the level of minority shareholder protection for each country (Protect $t_{j}$. We follow Rossi and Volpi (2004) and Hagendorff et al. (2008) and compute an index of shareholder protection that combines an index measuring the level of shareholder rights (revised anti-director index of Djankov et al. (2008)) and an index measuring the quality of law enforcement (the rule of law index from the Worldwide Governance Indicators (World Bank)). The anti-director index measures how strongly the legal system favors minority shareholders against managers or majority shareholders in the corporate decision making process, including the voting process; it ranges from from 0 to 5 . The rule of law index reflects perceptions of the

\footnotetext{
${ }^{9}$ The Zscore is defined as: $\left(\operatorname{MROA}(3)_{i j t}+E T A_{i j, t}\right) / \operatorname{SDROA}(3)_{i j, t}$, where $\operatorname{MROA}(3)_{i j, t}$ and $\operatorname{SDROA}(3)_{i j, t}$ are the moving average and standard deviation of return on assets (with a window width of 3 ), and $E T A_{i j, t}$ is the equity to total assets ratio at the date $t$. Higher Z-score means lower probability of default. ${ }^{10}$ A bank is classified as in "distress" over the period 2008-2012 if it bankrupted, received financial support from the government, or was absorbed by another bank due to financial difficulties. We have 19 banks in distress in our sample (out of 65 distress banks identified in the largest sample of BvD Bankscope). Only one of these 19 distress banks distributed dividends when having negative earnings.
} 
extent to which agents have confidence in and abide by the rules of society, and in particular the quality of contract enforcement, property rights, the police, and the courts; it ranges from -2.5 to $2.5 .^{11}$ The index Protect $_{j}$ is defined as the revised anti-director rights index multiplied by the rule of law index, and ranges from 0.7 to 8.84 , with a higher index indicating a higher level of shareholder protection. We compute the dummy variable High Protect Prat $_{j}$ that the value of one if the level of shareholder protection for the country $j$ is larger than the sample median, and zero otherwise. A positive relationship between High Protect $_{j}$ and dividend payouts is expected if minority shareholders having higher power force insiders to pay more dividends, in line with the outcome model proposed by La Porta et al. (2000). On the contrary, a negative relationship will support the substitute model of La Porta et al. (2000), where dividends are considered as a substitute for legal protection. It means that dividend payouts should be higher in countries with lower levels of minority shareholder protection than in countries with stronger levels of protection.

We ensure the absence of multicollinearity problems by computing the correlation matrix (see Table A2 in Appendix 1). We test for the presence of endogeneity between dividend payouts and the default risk variable $L n$ Zscore $_{i j, t .}$. We use the lags of Zscore and rule of law as instruments to perform the Durbin-Wu-Hausman test; the results show that Ln $_{\text {Zscore }} i j, t$ is not endogenous. ${ }^{12} \mathrm{We}$ also test for the presence of endogeneity between dividend payouts and our cluster dummy variables. Indeed, one could argue that investors could have incentives to buy shares of banks which pay higher dividends. We use as instruments the lagged values of the ownership variable. The results show that none of these variables are endogenous. Finally, we also test the potential endogeneity of our opacity index by using the lagged values of the opacity index as instruments, and we find that there is no endogeneity problem. ${ }^{13}$

\subsection{Augmented specifications}

We further analyze whether external factors (FACT) might influence the relationship between dividend policy, opacity and ownership structure. More specifically, we

\footnotetext{
${ }^{11}$ We compute the average value of the rule of law index over the period 2004-2012 for each country. It is almost time-invariant for our panel of European countries.

12 The test is available from the authors.

${ }^{13}$ Tests are available from the authors.
} 
examine if the institutional and regulatory environment, through the level of shareholder protection and the strength of the supervisory regime, is effective in shaping insiders' behavior (signaling or entrenchment). For this, we augment Equation (1) with interaction terms between the cluster dummy variables $C k_{i j, t}$, the dummy variable High Opacity $_{i j, t}$ and a dummy variable FACT as follows:

$$
\begin{gathered}
D P_{i j, t}=\sum_{\mathrm{k}=1}^{3} \gamma_{k} C k_{i j, t}+\sum_{k=1}^{3} \delta_{k} C k_{i j, t} * \text { High Opacity }_{i j, t}+\sum_{k=1}^{3} \varphi_{k} C k_{i j, t} * \text { FACT } \\
+\sum_{k=1}^{3} \varsigma_{k} C k_{i j, t} * \text { High Opacity } \text { Opj,t } * \text { FACT }+\sum_{\mathrm{k}=1}^{9} \beta_{k} \text { Controls }_{i j, t}+\alpha_{t}+\varepsilon_{i j, t}
\end{gathered}
$$

We first consider FACT as a dummy variable that differentiates countries with high and low levels of shareholder protection, using the dummy variable High Protect ${ }_{j}$ defined above. The payout ratios are given by the parameter $\left(\gamma_{k}\right)$ for banks with low degrees of opacity in countries with low levels of shareholder protection, by $\left(\gamma_{k}+\delta_{k}\right)$ for banks with high degrees of opacity in countries with low levels of shareholder protection, by $\left(\gamma_{k}+\varphi_{k}\right)$ for banks with low degrees of opacity in countries with high levels of shareholder protection, and by $\left(\gamma_{k}+\delta_{k}+\varphi_{k}+\varsigma_{k}\right)$ for banks high degrees of opacity in countries with high levels of shareholder protection.

Our aim is to examine whether the level of shareholder protection can influence the way European commercial banks determine their dividend policy in a context of agency conflict and information asymmetry. On the one hand, if our results are consistent with the entrenchment hypothesis, payout ratios of banks with higher degrees of opacity will be lower than the ones of banks with lower degrees of opacity. We expect that a higher level of shareholder protection can constraint such opportunistic behavior. In this case, payout ratios of banks with higher degrees of opacity located in countries with higher levels of shareholder protection should be lower than those in countries with lower levels of shareholder protection. On the other hand, if our results support the signaling hypothesis, payout ratios of banks with higher degrees of opacity will be higher than those with lower degrees of opacity. In this case, the expected impact of the level of shareholder protection on banks' behavior is not a clear cut issue. One might consider that the level of shareholder protection will not interfere in the relationship between the degree of opacity and payout ratios. However, higher levels of shareholder protection might reduce the need for more opaque banks to use dividends to signal to outsiders that they will not be expropriated. 
We alternatively examine whether the strength of supervisory regime has an influence on banks' dividend payouts when outsiders are under asymmetry of information. We use the index of supervisory power computed by Bart et al. (2004) to measure propensities of regulatory authorities to do on-site examinations in order to make an overall assessment of banks to determine their economic condition, and their ability to remove and replace managers and directors or to force a bank to change its internal organizational structure when problems are detected. The index Supervisory $y_{j}$ ranges in principle from 0 to 10 , with a higher index indicating stronger supervisory strength. In our sample, the index has a median of 5 and ranges from 4 to 9 . We compute the dummy variable Strong Supervisory S $_{j}$ that takes the value of one if the index of supervisory regime for the country $j$ is larger than the sample median, and zero otherwise. We expect that stronger supervisory regimes limit the entrenchment behavior of insiders. In this case, we should observe no significant differences between payout ratios for banks with high and low degrees of opacity in countries with stronger supervisory regimes, whereas these differences should be significant in countries with weaker supervisory regimes.

\section{Results}

\subsection{Opacity, ownership concentration and dividend policy}

The estimation results are given in Table 5. We use panel data regression with random effects to estimate Equation (1) as the variable High Protect j $_{j}$ is time invariant (column 1). ${ }^{14}$ We also run an Equation (1) without the interaction terms between the Cluster

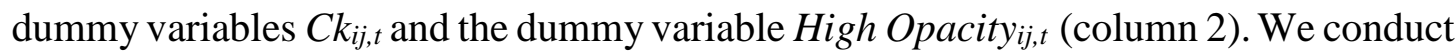
Wald tests to determine whether payout ratios significantly differ across Clusters $\mathrm{C} 1$, C2 and C3 depending on the degree of opacity. Results are provided in Table 6 (computed based on estimation results of column 1).

\footnotetext{
${ }^{14}$ As the variable High Protect $t_{j}$ is time invariant, we cannot use a fixed-effects model. Moreover, our ownership variables display little variation over time. According to Plumper and Troeger (2007), a fixedeffects model is inefficient in estimating the effect of variables that have such limited within variance. This inefficiency might lead to highly unreliable point estimates and may thus cause wrong inferences. We therefore decide to use a random-effect model; however, we find similar results when we use the Hausman-Taylor estimator.
} 
Results in Table 6 show that banks in Cluster 1 and Cluster 2 display significantly lower dividends when they have higher degrees of opacity compared to those with lower degrees of opacity. These results are in line with an entrenchment behavior either from managers (Cluster 1) or from majority shareholders (Cluster 2) when there is a high level of asymmetric information. However, we do not find such an entrenchment behavior for banks having a highly concentrated ownership structure (Cluster 3), as we do not observe significant differences in payout ratios for banks with high and low degrees of opacity. This difference of behavior between banks in Cluster 2 and Cluster 3 could be explained by the specific ownership characteristics of the latter. As highlighted in Table 3, majority shareholders of banks in Cluster 3 hold $100 \%$ of the shares for half of the observations and more than $98 \%$ of the shares for $75 \%$ of the observations. When majority shareholders hold such high levels of shares, they would act to maximise shareholders' wealth and not engage in expropriation of minority shareholders who are non-existent (or almost non-existent). Hence, there might be no incentives for an entrenchment behavior for banks in Cluster 3.

We further find that the average of the dividend payout ratio is increasing from Cluster 1 to 3 for banks with lower degrees of opacity, while we do not find any significant differences for banks with higher degrees of opacity. ${ }^{15}$ It means that dividend payments increase with the level of ownership concentration for banks with lower degree of opacity. This is consistent with majority shareholders trying to signal their unwillingness to use dividends to increase funds at their discretion, as it might be expected by minority shareholders, but only in banks where there is a low level of asymmetric information and where extraction of private benefit might be therefore easier to detect.

Taking all together, these results suggest that the entrenchment behavior we observe is related to higher degree of asymmetric information but not to higher levels of ownership concentration. We find that banks with either a dispersed or a concentrated ownership (but not highly concentrated) pay lower dividends when they display higher levels of information asymmetry compared to those with lower degrees of opacity. Our results therefore support the hypothesis of an entrenchment behavior of insiders when outsiders face high levels of asymmetric information, independently of the nature of the

\footnotetext{
${ }^{15}$ Wald tests are available on request.
} 
conflict of interest, be it either between managers/shareholders or majority shareholders/minority shareholders.

[Insert Tables 5 and 6 here]

\subsection{Effects of the institutional and regulatory environment}

We now examine whether the institutional and regulatory environment, more specifically the level of shareholder protection and the strength of the supervisory regime, could impede the entrenchment behavior observed for banks with higher degrees of opacity.

The estimation results, using random effects estimators, are given in the first two columns of Table 7. Table 8 and 9 report dividends payout ratios and Wald tests for banks with high and low degrees of opacity across clusters, according to the level of shareholder protection (Table 8) and the strength of the supervisory regime (Table 9). Firstly, we observe from Table 8 (Wald tests in column (a)) that banks belonging to Cluster 2 in countries with lower levels of shareholder protection have lower payout ratios when they have higher degrees of opacity compared to banks with lower degrees of opacity, in line with the entrenchment behavior. However, our results show that such opportunistic behavior does not exist in countries with higher levels of shareholder protection. This result does not hold for banks with a dispersed ownership (Cluster 1) as we find that they pay lower dividends when they are more opaque in countries with higher levels of shareholder protection. Our findings therefore show that higher levels of shareholder protection help to constraint the entrenchment behavior of majority shareholders but not the one of managers when the level of asymmetric information faced by outsiders is relatively high.

Wald tests in row (b) furthermore show that, for the same degree of opacity, banks dividend payments are higher in countries with lower levels of shareholder protection. This is consistent with the substitute model of La Porta et al. (2000), with dividends considered as a substitute for legal protection.

Secondly, we find for countries with weaker supervisory regimes that banks in Cluster 1 and Cluster 2 pay lower dividends when they display higher degrees of information asymmetry compared to those with lower degrees of opacity, in line with the entrenchment behavior (Table 9, column (a)). We do not observe such significant differences between dividend payouts for banks located in countries with stronger 
supervisory regimes. These results are consistent with the entrenchment behavior of insiders, managers and majority shareholders, being impeded in countries with stronger supervisory regimes. Higher propensities of regulatory authorities to conduct on-site examinations, greater ability of regulator to constrain banks' corporate governance when problems are detected help to mitigate insiders' entrenchment behavior and then reduce minority shareholder expropriation.

[Insert Tables 7 to 9 here]

\subsection{Impact of the 2008 global financial crisis}

We further investigate whether European banks change their dividend policy during the financial crisis of 2007-2008 and the following sovereign debt crisis. Acharya et al. (2011) report that banks in the U.S. and in Europe had been paying out significant dividends before the crisis period (2000-2006), but also during the crisis period (20072008). The authors explain the persistence of dividend payments during the crisis period by the conflict of interest between shareholders and debtholders that leads shareholders to prefer immediate payouts when banks are financially distressed. Dividends are then paid to shareholders at the expense of debtholders, including regulators and taxpayers who fund bailouts. Kanas (2013) also provides evidence that the Prompt Corrective Action framework was ineffective in curbing dividend behavior. However, he also shows that the introduction of the Troubled Asset Relief Program and the increase in the deposit insurance cap in 2008 entail the elimination of both effects. Abreu and Gulamhussen (2013) find that even U.S. bank holding companies that were undercapitalized before the financial crisis of 2007-2008 paid higher dividends, but they stop doing so during the financial crisis when regulators pressure was greater.

In line with this literature, we examine whether European banks have changed their dividend policy during the financial crisis compared to the non-crisis period; more specifically we aim to address whether banks with high degrees of opacity relax or amplify their entrenchment behavior during the crisis period. In order to address this issue, we rely on the specification in Equation (2) where the variable FACT now represents the dummy variable Crisist, taking the value of one during the financial crisis period 2007-2012 and zero otherwise. The estimation results are given in the third column of Table 7 and Table 10 provides dividend payout ratios and Wald tests for 
banks with high and low degrees of opacity across clusters, before and during the financial crisis period.

Our results show that banks in Clusters 1 and 2 do not change their behavior during the crisis period compared to the non-crisis period (see Wald tests in Table 10, column (a)). For these two clusters, we observe as previously that banks with higher degrees of opacity pay fewer dividends than banks with lower degrees of opacity, not just during the non-crisis period but also during the crisis period. The persistence of the entrenchment behavior of insiders (either managers or majority shareholders) during the crisis period indicates that benefits of any private extraction dominate those of increasing immediate payments during a period of financial trouble.

Our findings also confirm the stylized facts of Acharya et al. (2011) that European commercial banks do not reduce their dividend payments during the crisis period (see Wald tests, row (b)).

[Insert Table 10 here]

\section{Robustness checks}

We carry out several additional robustness checks on our empirical results. ${ }^{16}$

Firstly, we employ two alternative variables to measure the dividend payout: the ratio dividends to equity and the ratio dividends to total assets. The results obtained in Tables 5 to 10 are robust when we use these two measures as dependent variables.

Secondly, we use the ratio measuring the relative power of the second-largest shareholder compared to the largest shareholder (Share $2_{i j, t} /$ Share $_{i j, t}$ ) instead of the shares held by the second-largest shareholder $\left(\operatorname{Share}_{i j, t}\right)$ to construct our clusters. We rerun our Equations (1) and (2) and we find similar results.

We then rerun our Equations (1) and (2) by excluding banks that change clusters during the sample period; this leaves again our results unchanged.

We further use the third quartile of the index Opacity $_{i j, t}$ and Protect $_{j}$ instead of the median of the sample to define the dummy variables High Opacity $_{i j, t}$ and High Protect ${ }_{j}$. Our results are unchanged with high levels of shareholder protection that help to constraint the opportunistic entrenchment behavior of majority shareholders in banks that display high degrees of opacity, while stronger supervisory regimes moderate the

\footnotetext{
${ }^{16}$ The estimation results not included in this section are available on request.
} 
opportunistic behavior of both managers and majority shareholders. We also use the indices Ppacity $_{i j, t}$ and Protect $_{j}$ in levels instead of dummy variables and calculate the relevant marginal effects, with Opacity $_{i j, t}$ and Protect $_{j}$ evaluated at minimum, median and maximum levels. We find similar results when the index Opacity $_{i j, t}$ and Protect $_{j}$ are relatively high, i.e. above the median of the sample.

Finally, we investigate whether the type of the majority shareholder has an impact on the dividend policy of banks. The existing literature highlights that dividend payments are dependent on the identity of the largest shareholder. Institutional investors as majority shareholder have the resources, expertise and incentives to monitor and influence dividend payments. Prior empirical studies show that institutional investors require firms to pay dividends to enjoy preferential tax treatment, but without demanding higher payout ratios (e.g. Grinstein and Michaely 2005, Renneboog and Trojanowski 2006). Banking firms are also often credited with having a comparative advantage in monitoring firms. In line with this hypothesis, Goergen et al (2005) find that firms with banks as major shareholder are more willing to omit dividend payments than firms controlled by other types of shareholder. Families as majority shareholders, on the other hand, might have stronger incentives to pursue private benefits (Claessens et al., 2002). However, prior empirical studies find that dividend payout ratios are lowest in firms controlled by individuals or families (e.g. Gugler 2003, Renneboog and Trojanowski 2006). This can be linked to reputational effects and controlling families caring about the long-term viability of the firm, resulting in higher monitoring of managers.

To investigate the impact of the type of the majority shareholder on dividend payout ratios, we follow the BvD Bankscope classification in differentiating between the shareholder types. We compute five different dummy variables taking the value of one if the majority shareholder is either a bank, an institutional investor, an industrial firm, a state, or an individual/family. We put all the remaining categories of shareholders (managers, public, foundations, and unnamed shareholders) in the category "others". ${ }^{17}$ In our sample, banks' dominant shareholders fall predominantly into the categories of banks, institutional investors and industrial firms. Dominant shareholdings by the government and individuals/families, on the other hand, are much less common in our

\footnotetext{
${ }^{17} \mathrm{We}$ do not have enough observations for this to consider them as separate groups.
} 
sample. As we only have 9 banks where the majority shareholder is state and 33 banks where the majority shareholder is an individual/family, we can only run Equation (1) by replacing the cluster dummy variables by the shareholder type dummy variables, but we cannot run Equation (2) where we need to further differentiate banks according to their degree of opacity. Table A3 in Appendix 1 shows that banks which pay the lowest dividends are those where the majority shareholder is an individual or a family. This is consistent with the hypothesis that the incentives for expropriation might be stronger for individuals/families as they are more able to efficiently divert benefits to themselves (Claessens et al., 2002). The highest dividends are paid when the majority shareholder is a bank, in line with the findings of Goergen et al. (2005).

We then test that are our results are not driven by banks where the dominant shareholder is an individual or a family by excluding them. We rerun our Equations (1) and we find similar results, with significantly higher payout ratios for banks in Clusters 1 and 2 having higher degrees of opacity.

\section{Conclusion}

We empirically examined whether dividend payout decisions of banks depend on the degree of asymmetric information faced by their outsiders, and on the level of ownership concentration. For this, we built a novel database on listed and non-listed European commercial banks for the period 2004-2012 with detailed information on banks' individual ownership structure. We used a clustering approach to distinguish between banks with different degrees of ownership concentration. We also constructed a synthetic measure of banks' opacity for listed and non-listed banks based on four sources of information asymmetry.

We find that banks with either a concentrated or a dispersed ownership structure have lower payout ratios when they have higher degrees of opacity. These results support the entrenchment behavior for banks displaying higher degree of opacity and where extraction of private benefit might be therefore more difficult to detect, with insiders (either managers or majority shareholders) decreasing dividends to potentially increase the amount of free cash flow they can divert for their private consumption. Our results therefore support the hypothesis of an entrenchment behavior of insiders, independently of the nature of the conflict of interest, be it either between managers/shareholders or majority shareholders/minority shareholders. 
Further analysis shows that a higher level of shareholder protection helps to constrain the entrenchment behavior of majority shareholder but not the one of managers. However, we find that stronger supervisory regimes where regulatory authorities do onsite examinations in order to make an overall assessment of banks, contribute to moderate the entrenchment behavior of both majority shareholders and managers. We also find that banks' dividend payout decisions are not modified during the crisis period compared to the non-crisis period.

Our results provide therefore robust empirical support for the entrenchment behavior for banks with either a concentrated or a dispersed ownership structure when outsiders face a relatively high degree of asymmetric information. This is a problem that might make it more difficult for banks to raise capital. It is therefore worthwhile to determine governance mechanisms that could lead to an optimal dividend policy to protect and attract minority shareholders.

Our findings are in line with the recommendation of the Federal Reserve Board (FRB, 2011) and the Basel Committee on Banking Supervision (BCBS, 2011) of having greater oversight over the dividend policy of banks. The reform of Basel 3 suggests imposing restrictions on dividends for banks that do not satisfy regulatory solvency requirements. However, our findings suggest that such restrictions might have an unintended impact by amplifying the entrenchment behavior of banks with high degrees of opacity.

If regulators want to allow signaling and agency mechanisms to function, this requires a lessening of information asymmetry by doing on-site examinations and imposing more transparency and strict information disclosures. Our findings also suggest that existing corporate mechanisms need to be improved to mitigate agency conflicts between insiders (managers or majority shareholders) and outsiders. Overall, to arrive at more efficient capital markets in Europe, better corporate governance mechanisms and increased transparency are called for. 


\section{References}

Abreu, J.F., Gulamhussen, M.A., 2013. Dividend Payouts: Evidence from U.S. Bank Holding Companies in the Context of the Financial Crisis. Journal of Corporate Finance 22, 54-65.

Acharya, V.V., Gujral, I., Shin, H.S., 2009. Dividends and Bank Capital in the Financial Crisis of 2007-2009. SSRN.

Acharya, V.V., Gujral, I., Kulkarni, N., Shin, H.S., 2011. Dividends and Bank Capital in the Financial Crisis of 2007-2009. NBER Working Paper No. 16896 (Cambridge, MA: NBER).

Acharya, V.V., Le, H.T., Shin, H.S., 2013. Bank Capital and Dividend Externalities. CEPR Discussion Paper No. DP9479.

Ahmed, A., Takeda, C., Thomas, S., 1999. Bank loan loss provisions: a re-examination of capital management, earnings management and signaling effects. Journal of Accounting and Economics 28, 1-26.

Anandarajan, A., Hasan, I., McCarthy, C., 2007. Use of loan loss provisions for capital, earnings management and signalling by Australian banks. Accounting \& Finance 47, 357-379.

Arellano, M., Bover, O., 1995. Another look at the Instrumental Variable Estimation of Error-Components Models. Journal of Econometrics 8, 29-51.

Banerjee, S., Gatchev V., Spindt, P., 2007. Stock market liquidity and firm dividend. Journal of Financial and Quantitative Analysis 42, 369-397.

Barth, J. R., Caprio, G., Levine, R., 2004. Bank supervision and regulation: what works best?" Journal of Financial Intermediation 13, 205-48.

Basel Committee on Banking Supervision, 2011. Basel III: a global regulatory framework for more resilient banks and banking systems (Bank for International Settlements).

Benartzi, S., Michaely, R., Thaler, R., 1997. Do Changes in Dividends Signal the Future or the Past? The Journal of Finance 52, 1007-1034.

Berlin, M., Loeys, J.G., 1988. Bond Covenants and Delegated Monitoring. The Journal of Finance 43 397-412.

Bessler, W., Nohel, T., 1996. The Stock-Market Reaction to Dividend Cuts and Omissions by Commercial Banks. Journal of Banking \& Finance 20, 14851508 .

Bikker, J., Metzemakers, P., 2005. Bank provisioning behaviour and procyclicality. Journal of International Financial Markets, Institutions and Money 15, 141-157.

Bøhren, Ø., Josefsen, M.G., Steen, P.E., 2012. Stakeholder Conflicts and Dividend Policy. Journal of Banking \& Finance 36, 2852-2864.

Bouvatier, V., Lepetit, L. (2008). Banks' procyclical behavior: does provisioning matter? Journal of International Financial Markets, Institutions, and Money 18, $513-26$

Bouvatier, V., Lepetit, L., Strobel, F., 2014. Bank Income Smoothing, Ownership Concentration and the Regulatory Environment. Journal of Banking \& Finance 41, 253-270.

Brockman, P., Unlu, E. (2011). Earned/contributed capital, dividend policy, and disclosure quality: An international study. Journal of Banking \& Finance, 1610 1625.

Campbell, T., Kracaw, W., 1980. Information production, market signaling, and the theory of intermediation. The Journal of Finance 35, 863-882. 
Chae, J., Kim, S., Jung Lee, E., 2009. How corporate governance affects payout policy under agency problems and external financing constraints. Journal of Banking \& Finance 33, 2093-2101.

Chen, K.C.W., Chen, Z., Wei, K.C.J., 2009. Legal protection of investors, corporate governance, and the cost of equity capital. Journal of Corporate Finance 15, 273-289.

Chu, T., Haw, I. M., Lee, B. B. H., Wu, W. 2014. Cost of equity capital, control divergence, and institutions: the international evidence. Review of Quantitative Finance and Accounting 43, 483-527.

Claessens, S., Djankov, S., Fan, J.P.H., Lang, L.H.P., 2002. Disentangling the Incentive and Entrenchment Effects of Large Shareholdings. The Journal of Finance 57, 2741-2771.

Cornett, M.M., McNutt, J.J., Tehranian, H., 2009. Corporate governance and earnings management at large U.S. bank holding companies. Journal of Corporate Finance 15, 412-430.

Crouzille, C., Lepetit, L., Tarazi, A., 2004. Bank Stock Volatility, News and Asymmetric Information in Banking: An Empirical Investigation. Journal of Multinational Financial Management 14, 443_461

Davies, P.L., 2000. The board of directors: composition, structure, duties and powers. Paper on Company Law Reform in OECD Countries: A Comparative Outlook of Current Trends.

Dechow, P., and Dichev, I.D., 2002. The quality of accruals and earnings: the role accruals estimation errors, The Accounting Review 77, 35-59

De Cesari, A., 2012. Expropriation of Minority Shareholders and Payout Policy. The British Accounting Review 44, 207-220.

Denis, D.J., Denis, D.K., Sarin, A., 1994. The Information Content of Dividend Changes: Cash Flow Signaling, Overinvestment, and Dividend Clienteles. Journal of Financial and Quantitative Analysis 29, 567-587.

Diamond, D.W., 1991, Monitoring and Reputation: The Choice between Bank Loans and Directly Placed Debt. Journal of Political Economy 99, 689-721.

Dickens, R.N., Casey, K.M., Newman, J.A., 2002. Bank dividend policy: explanatory factors, Quaterly Journal of Business and Economics 41, 3-12.

Diether, K.B., Malloy, C.J. Scherbina, A., 2002. Differences of opinion and the crosssection of stock returns. The Journal of Finance 57, 2113-2142.

Djankov, S., La Porta, R., Lopez-de-Silanes, F., Shleifer, A., 2008. The Law and Economics of Self-Dealing. Journal of Financial Economics 88, 430-465.

Easterbrook, F.H., 1984. Two Agency-Cost Explanations of Dividends. American Economic Review 74, 650-659.

Faccio, M. , Lang, L.H.P., Young, L. (2001). Dividends and Expropriation. American Economic Review 91, 54-78.

Fama, E.F., French, K.R., 2001. Disappearing Dividends: Changing Firm Characteristics or Lower Propensity to Pay? Journal of Financial Economics 60, 3-43.

Federal Reserve Board, 2011. Federal Reserve System, 12 CFR Part 225, capital plans. Fed. Regist. 76 (231), 74631-74648. 
Filbeck, G., Mullienaux, D.J., 1993. Regulatory Monitoring and The Impact of Bank Holding Company Dividend Changes on Equity return. Financial Review 28, 403-415.

Filbeck, G., Mullienaux, D.J., 1999. Agency Cost and Dividend Payment: The Case of Bank Holding Companies. The Quarterly Review of Economics and Finance, 409-418.

Fidrmuc, J.P., Jacob, M., 2010. Culture, Agency Costs, and Dividends. Journal of Comparative Economics 38, 321-339.

Galiakhmetova, R., Jiaotong, X., Molyneux P., Onali E., 2015. CEO power, government monitoring, and bank dividends, mimeo.

Goergen, M., Renneboog, L., Correira da Silva, L., 2005. When do German firms change their dividends? Journal of Corporate Finance 11, 375-399.

Gomes, A., 2000. Going public without governance: Managerial reputation effects. The Journal of Finance 55, 615-646.

Goyal V.K., 2005. Market Discipline of Bank Risk: Evidence from Subordinated Debt Contracts, Journal of Financial Intermediation 14, 318-50.

Greenawalt, M., Sinkey, J., 1988. Bank loan-loss provisions and the incomesmoothing hypothesis: an empirical analysis, 1976-1984. Journal of Financial Services Research 1, 301-318.

Grinstein, Y., Michaely, R., 2005. Institutional holdings and payout policy, Journal of Finance 60, 1389-1426.

Gugler, G., 2003. Corporate governance, dividend payout policy, and the interrelation between diviends, $R \& D$, and capital investment. Journal of Banking \& Finance 27, 1297-1321.

Gugler, K., Yurtoglu, B.B., 2003. Corporate Governance and Dividend Pay-out Policy in Germany. European Economic Review 47, 731-758

Hagendorff, J., Collins, M., Keasey, K., 2008. Investor protection and the value effects of bank merger announcements in Europe and the US. Journal of Banking \& Finance 32, 1333-1348.

Healey, P.M., Papelu, K.G., 1988. Earnings information conveyed by dividend initiations and omissions, Journal of Financial Economics 21, 149-175.

Hutton, A.P., Marcus, A.J., Tehranian, H., 2009. Opaque financial report, R $^{2}$, and crash risk, Journal of Financial Economics 94, 67-86.

James C., 1991. The Losses Realized in Bank Failures, The Journal of Finance 46, 223 42.

Jensen, M.C., Meckling, W., 1976. Theory of the firm: Managerial behavior, agency costs, and capital structure. Journal of Financial Economics 3, 305-360.

Kanas, A., 2013. Dividends, risk, and regulatory regimes. Journal of Banking \& Finance 37, 1-10.

Krishnaswami, S., Subramaniam, V., 1999. Information Asymmetry, Valuation, and the Corporate Spin-Off Decission. Journal of Financial Economics 53, 73-112.

Lang, M.H., Maffett, M.G., 2011. Transparency and liquidity uncertainty in crisis period. Journal of Accounting and Economics 52, 101-125.

Lang, L.H., Litzenberger, R., 1989. Dividend announcements: Cash flow signalling vs. free cash flow hypothesis. Journal of Financial Economics 24, 181-191.

La Porta, R., Lopez-de-Silanes, F., Shleifer, A., Vishny, R.W., 1998. Law and Finance. Journal of Political Economics 106, 1113-1155. 
La Porta, R., Lopez-de-Silanes, F., Shleifer, A., Vishny, R.W., 2000. Agency Problems and Dividend Policies around the World. The Journal of Finance 55, 1-33.

Leary, M.T., Michaely, R., 2011. Determinants of dividend smoothing: empirical evidence. The Review of Financial Studies 24, 3197-3249.

Lemmon, M. L., Lins, K. V., 2003. Ownership structure, corporate governance, and firm value: Evidence from the East Asian financial crisis. The Journal of Finance. 58, 1445-1468.

Lepetit, L. Strobel, F., 2015, Bank Insolvency Risk and Z-Score Measures : A Refinement. Finance Research Letters 13, 214-224.

Leuz, C., Nanda, D., Wysocki, P., 2003. Earnings management and investor protection: an international comparison. Journal of Financial Economics 69, 505-527.

Li, K., Zhao, X., 2008. Asymmetric Information and Dividend Policy. Financial Management 37, 673-694.

Lins, Karl V., 2003. Equity ownership and firm value in emerging markets, Journal of Financial and Quantitative Analysis. 38, 159-184.

Morgan, D.P., 2002. Rating Banks: Risk and Uncertainty in An Opaque Industry. American Economic Review 92, 874-888.

Onali, E., 2014. Moral Hazard, Dividends, and Risk in Banks. Journal of Business Finance \& Accounting 41, 128-155.

Park, S., 1999. Effects of Risk-Based Capital Requirements and Asymmetric Information on Banks' Portfolio Decisions. Journal of Regulatory Economics $16,135-150$.

Plumper, T., Troeger, V.E., 2007. Efficient Estimation of Time-Invariant and Rarely Changing Variables in Finite Sample Panel Analyses with Unit Fixed Effects. Political Analysis 15, 124-139.

Renneboog, L., Trojanowski, G., 2006. Control structures and payout policy. Managerial Finance 33, 43-64.

Rossi, S., Volpin, P.F., 2004. Cross-country determinants of mergers and acquisitions. Journal of Financial Economics 74, 277-304.

Sáez, M. I., Riaño, D., 2013. Corporate governance and the shareholders meeting: voting and litigation. European Business Organization Law Review 14, 343399.

Shleifer, A., Vishny, R.W., 1997. A Survey of Corporate Governance. The Journal of Finance 52, 737-783.

Theis, J., Dutta, A.S., 2009. Explanatory factors of bank dividend policy: Revisited, Journal of Corporate Finance, 35, 501-508.

Von Eije, H., Megginson, W.L., 2008. Dividends and Share Repurchases in the European Union. Journal of Financial Economics 89, 347-374.

Windmeijer, F., 2005. A Finite Sample Correction for the Variance of Linear Efficient Two-Step GMM Estimators. Journal of Econometrics 126, 25-51.

Yoon, P.S., Starks, L.T., 1995. Signaling, Investment Opportunities, and Dividend, Announcements. Review of Financial Studies 8, 995-1018.

Zwiebel, J., 1996. Dynamic capital structure under managerial entrenchment. American Economic Review 86, 1197-1215. 
Table 1. Distribution of banks by country

\begin{tabular}{lccc}
\hline Country & $\begin{array}{c}\text { Our sample of } \\
\text { commercial banks }\end{array}$ & $\begin{array}{c}\text { Full sample of } \\
\text { commercial banks } \\
\text { in Bankscope }\end{array}$ & $\begin{array}{c}\text { Percent of } \\
\text { total assets }\end{array}$ \\
\hline Austria & 12 & 80 & 56.18 \\
Belgium & 7 & 38 & 36.11 \\
Denmark & 34 & 58 & 53.31 \\
Finland & 4 & 10 & 72.52 \\
France & 53 & 147 & 45.45 \\
Germany & 21 & 151 & 60.94 \\
Greece & 9 & 20 & 61.65 \\
Ireland & 5 & 18 & 44.06 \\
Italy & 58 & 142 & 54.63 \\
Luxembourg & 36 & 88 & 26.79 \\
Netherlands & 12 & 40 & 44.45 \\
Portugal & 7 & 27 & 41.32 \\
Spain & 18 & 69 & 81.54 \\
Sweden & 11 & 26 & 72.25 \\
U.K. & 43 & 148 & 50.31 \\
\hline Total & 330 & 1062 & Median $=53.31$ \\
\hline Percent of total assets represents the average of total assets of commercial banks in our sample for \\
the year 2004-2012 divided by the average of total assets of commercial banks of the full sample of \\
banks provided by BvD Bankscope for the year 2004-2012. &
\end{tabular}


Table 2. General descriptive statistics, on average over the period 2004-2012

\begin{tabular}{|c|c|c|c|c|c|c|c|c|c|c|}
\hline & Deposit & ETA & Loan & LLP & $\mathrm{ROA}$ & $\mathrm{ROE}$ & NII & Expenses & TA & DP \\
\hline \multicolumn{11}{|c|}{ Our sample of commercial banks } \\
\hline \multicolumn{11}{|c|}{ All banks (330 banks, 1,150 observations) } \\
\hline Mean & 53.90 & 7.02 & 56.35 & 0.28 & 0.86 & 12.99 & 40.05 & 58.10 & 143,122 & 46.08 \\
\hline Std. Dev. & 20.05 & 3.68 & 23.60 & 0.43 & 0.81 & 9.40 & 15.95 & 13.15 & 404,462 & 29.71 \\
\hline Minimum & 10.46 & 0.42 & 0.40 & -6.06 & -7.00 & -59.04 & -26.67 & 10.00 & 50 & 0 \\
\hline Maximum & 91.97 & 21.30 & 94.13 & 4.14 & 9.26 & 77.91 & 87.50 & 87.37 & $3,424,403$ & 100 \\
\hline \multicolumn{11}{|c|}{ Cluster 1 Dispersed ownership (89 banks, 294 observations) } \\
\hline Mean & 51.20 & 7.20 & 61.96 & 0.31 & 0.85 & 12.34 & 38.22 & 58.32 & 306,390 & 32.32 \\
\hline Std. Dev. & 18.54 & 3.84 & 17.24 & 0.43 & 0.77 & 6.91 & 13.10 & 10.78 & 650,455 & 22.48 \\
\hline \multicolumn{11}{|c|}{ Cluster 2 Concentrated ownership (119 banks, 307 observations) } \\
\hline Mean & 51.85 & 7.83 & 60.13 & 0.36 & 0.80 & 10.96 & 37.62 & 58.91 & 86,902 & 46.29 \\
\hline Std. Dev. & 18.35 & 3.84 & 24.04 & 0.37 & 0.70 & 8.94 & 14.36 & 13.28 & 288,810 & 28.71 \\
\hline \multicolumn{11}{|c|}{ Cluster 3 Highly concentrated ownership (187 banks, 549 observations) } \\
\hline Mean & 56.42 & 6.47 & 51.15 & 0.22 & 0.90 & 14.50 & 42.62 & 57.58 & 87,429 & 53.88 \\
\hline Std. Dev. & 21.50 & 3.39 & 25.20 & 0.46 & 0.88 & 10.53 & 17.72 & 14.20 & 227,734 & 30.95 \\
\hline
\end{tabular}

Variable definitions (all variables are expressed in percentages, except TA which is in millions of USD): Deposit = deposits/total assets; ETA = total equity/total assets; Loan $=$ net loans/total assets; $L L P=$ loan loss provisions/total assets; $R O A=$ net income/total assets; $R O E=$ net income/total equity; NII = non-interest income/operating profit; Expenses $=$ operating expenses/operating profit; $T A=$ total assets; DP = cash dividend related to the period/earnings.

Clusters 1-3 are determined using a hierarchical agglomerative clustering (HAC) approach that uses three ownership measures in the construction of clusters of banks with "similar" ownership characteristics: the percentage held by the largest shareholder, the percentage held by the second-largest shareholder, and a Herfindahl index computed for a bank's ownership distribution. 
Table 3. Descriptive statistics on ownership measures by cluster, on average over the period 2004-2012.

\begin{tabular}{|c|c|c|c|c|}
\hline & Share1 & Share2 & Share2/Share1 & Concentration \\
\hline \multicolumn{5}{|c|}{ All banks $(1,150$ observations $)$} \\
\hline mean & 68.13 & 8.54 & 0.27 & 0.61 \\
\hline sd & 35.25 & 11.84 & 0.34 & 0.39 \\
\hline $\min$ & 0.01 & 0 & 0 & 0.00 \\
\hline p25 & 42 & 0 & 0 & 0.24 \\
\hline p50 & 80 & 3.32 & 0.08 & 0.66 \\
\hline p75 & 100 & 13 & 0.50 & 1 \\
\hline $\max$ & 100 & 50 & 1 & 1 \\
\hline \multicolumn{5}{|c|}{ Cluster 1 Dispersed ownership (294 observations) } \\
\hline mean & 15.39 & 10.32 & 0.65 & 0.07 \\
\hline sd & 12.86 & 9.05 & 0.30 & 0.08 \\
\hline $\min$ & 0.01 & 0.01 & 0.01 & 0.00 \\
\hline $\mathrm{p} 25$ & 5 & 4.99 & 0.42 & 0.00 \\
\hline p50 & 10.16 & 6.19 & 0.72 & 0.02 \\
\hline p75 & 25.00 & 16.48 & 0.94 & 0.11 \\
\hline $\max$ & 42.18 & 41.00 & 1 & 0.34 \\
\hline \multicolumn{5}{|c|}{ Cluster 2 Concentrated ownership (307 observations) } \\
\hline mean & 62.69 & 20.18 & 0.34 & 0.46 \\
\hline sd & 12.32 & 13.53 & 0.26 & 0.15 \\
\hline $\min$ & 43.37 & 0.01 & 0.00 & 0.20 \\
\hline p25 & 51.00 & 8.72 & 0.13 & 0.30 \\
\hline $\mathrm{p} 50$ & 60 & 19.69 & 0.30 & 0.47 \\
\hline p75 & 75 & 28.95 & 0.50 & 0.59 \\
\hline $\max$ & 85.83 & 50 & 1 & 0.76 \\
\hline \multicolumn{5}{|c|}{ Cluster 3 Highly concentrated ownership (549 observations) } \\
\hline mean & 98.71 & 0.60 & 0.01 & 0.98 \\
\hline sd & 2.65 & 1.79 & 0.02 & 0.05 \\
\hline $\min$ & 86.67 & 0 & 0 & 0.75 \\
\hline p25 & 98 & 0 & 0 & 0.96 \\
\hline p50 & 100 & 0 & 0 & 1 \\
\hline p75 & 100 & 0 & 0 & 1 \\
\hline $\max$ & 100 & 10 & 0.11 & 1 \\
\hline
\end{tabular}

Variable definitions: Share1 $=$ percentage held by largest shareholder; Share $2=$ percentage held by second-largest shareholder; Share2/Share1 = relative (voting) power of the second largest shareholder compared to the largest shareholder; Concentration = Herfindahl index on bank's ownership distribution (we compute for each bank $i$ the variable $O S_{i}$, defined by the ratio of the percentage of equity held by each shareholder $n$ to the total percentage of equity held by all shareholders; we then compute Concentration as $\sum_{n=1}^{N} O S_{n}^{2}$ with $N$ the total number of shareholders).

Clusters 1-3 are determined using a hierarchical agglomerative clustering (HAC) approach that uses three ownership measures (Share1, Share2 and Concentration) in the construction of clusters of banks with "similar" ownership characteristics 
Table 4. Descriptive statistics of opacity measures, on average over the period 2004-2012.

\begin{tabular}{lcrrrr}
\hline & Opacity & EM & EF & MF & Loan \\
\hline All banks (1,150 observations) & 5.62 & 0.60 & 0.34 & 13.80 & 57.45 \\
Mean & 1.37 & 0.70 & 0.45 & 14.11 & 22.91 \\
Std. Dev. & 2.25 & -4.86 & 0 & 0 & 0.40 \\
Minimum & 9.25 & 6.86 & 6.26 & 79.61 & 94.13 \\
Maximum & & & & \\
Cluster 1 Dispersed ownership (294 observations) & 5.44 & 0.58 & 0.30 & 18.46 & 62.13 \\
Mean & 1.34 & 0.76 & 0.41 & 15.46 & 16.34 \\
Std. Dev. & 5.80 & 0.62 & 0.37 & 14.55 & 60.12 \\
Cluster 2 Concentrated ownership (307 observations) & & & & \\
Mean & 1.43 & 0.53 & 0.57 & 13.81 & 23.24 \\
Std. Dev. & & & & \\
Cluster 3 Highly concentrated ownership (549 observations) & & & & \\
Mean & 5.62 & 0.59 & 0.34 & 10.94 & 53.36 \\
Std. Dev. & 1.33 & 0.74 & 0.39 & 12.87 & 24.99 \\
\hline
\end{tabular}

Variable definitions: Opacity = composite index of four opacity measures $(E F, E M, M F$, and Loan as defined in section 2.3); EM=earnings management; $E F=$ earnings forecast error; $M F=$ the negative value of (long term + short term market funding)/total assets; Loan = net loans/total assets,

Clusters 1-3 are determined using a hierarchical agglomerative clustering (HAC) approach that uses three ownership measures in the construction of clusters of banks with "similar" ownership characteristics: the percentage held by the largest shareholder, the percentage held by the second-largest shareholder, and a Herfindahl index computed for a bank's ownership distribution. 
Table 5. Degree of opacity, ownership concentration \& dividend policy of European banks for the period 2004-2012.

\begin{tabular}{lcc}
\hline Dependent: DP & (Equation 1) & (Equation 1 without interaction terms) \\
\hline C1 & $30.98^{* * *}$ & $32.90^{* * *}$ \\
& $(3.45)$ & $(3.19)$ \\
C2 & $39.05^{* * *}$ & $39.97 * * *$
\end{tabular}

C3

$$
40.50 * * *
$$

C1*High Opacity

C2*High Opacity

C3*High Opacity

Opacity

High Protect

ROA

Assets growth

Size

M \& A

High Charter

Distress

Variable definitions: Dependent variable: $D P=$ cash dividend related to the period/earnings. Independent variables: $C 1-C 3=$ clusters dummy variables; Opacity=composite index of four opacity measures (EF, EM, MF, and Loan as defined in section 2.3); High Opacity = dummy variable equals one if the opacity composite index of a bank is higher than the sample median; High Protect $=$ dummy variable equals one if the index for degree of minority shareholders protection is higher than the sample median; ROA = Return on Assets; Assets growth = annual growth of total assets; size = log of total assets; $M \& A=$ dummy variable equals one the year a bank acquires another financial institutions; Ln ZScore = log of z score, calculated over 3-year rolling windows; High Capitalized = dummy variables equals one if the bank risk-weighted capital ratio at the beginning of the period is larger than sample median; High Charter = dummy variable equals one if the ratio of customer deposits to total assets is larger than the sample median; Distress=dummy variable takes value of one if banks are distressed; GDP growth = annual GDPgrowth. z-statistics are in parentheses, with $p<0.1 *, p<0.05 * *$ and $p<0.01 * * *$. Standard error is adjusted for clustering on bank. 
Table 6. Dividend payout of banks according to the degree of opacity High Opacity

Low Opacity

High - Low Opacity

\begin{tabular}{lccc}
\hline $\mathrm{C} 1$ & $24.52 * * *$ & $30.98^{* * *}$ & $-6.45^{* *}$ \\
& $(0.00)$ & $(0.00)$ & $(0.02)$ \\
$\mathrm{C} 2$ & $30.54 * * *$ & $39.95^{* * *}$ & $-8.51^{* * *}$ \\
& $(0.00)$ & $(0.00)$ & $(0.00)$ \\
$\mathrm{C} 3$ & $38.98^{* * *}$ & $40.50^{* * *}$ & -1.51 \\
& $(0.00)$ & $(0.00)$ & $(0.56)$ \\
\hline
\end{tabular}

Variable definitions: $\mathrm{Cl}$-C3 = clusters dummy variables; High Opacity = Banks with high opacity, dummy variable equals one if the opacity composite index of a bank is higher than the sample median. The coefficient represents the average of dividend payout of each clusters on each opacity condition. It is computed form equation 1, where average dividend payout for banks with low opacity is the coefficient of $C k(\gamma k)$ and for banks with high opacity is coefficient $C k+C k *$ Opacity $(\gamma k+\delta k)$. P-value are in parentheses, with $p<0.1^{*}, p<0.05^{* *}$ and $p<0.01 * * *$. 
Table 7. Degree of opacity, ownership concentration and dividend policy for different levels of shareholder protection and supervisory regime strength, and before/during the crisis period, for European commercial banks over the period 2004-2014 (Equation (2))

\begin{tabular}{|c|c|c|c|}
\hline \multirow[b]{2}{*}{ Dependent: DP } & \multicolumn{3}{|c|}{ FACT } \\
\hline & High Protect & $\begin{array}{c}\text { Strong } \\
\text { Supervisory }\end{array}$ & Crisis \\
\hline $\mathrm{C} 1$ & $\begin{array}{l}32.32 * * * \\
(3.68)\end{array}$ & $\begin{array}{l}27.72 * * * \\
(3.16)\end{array}$ & $\begin{array}{l}25.11 * * * \\
(2.82)\end{array}$ \\
\hline $\mathrm{C} 2$ & $\begin{array}{l}43.97 * * * \\
(5.33)\end{array}$ & $\begin{array}{l}37.92 * * * \\
(4.47)\end{array}$ & $\begin{array}{l}36.78 * * * \\
(4.22)\end{array}$ \\
\hline $\mathrm{C} 3$ & $\begin{array}{l}43.91 * * * \\
(5.33)\end{array}$ & $\begin{array}{l}40.55 * * * \\
(4.73)\end{array}$ & $\begin{array}{l}37.39 * * * \\
(4.19)\end{array}$ \\
\hline C1* High Opacity & $\begin{array}{l}0.02 \\
(0.00)\end{array}$ & $\begin{array}{l}-8.29 * * \\
(-2.12)\end{array}$ & $\begin{array}{l}-5.48 \\
(-1.58)\end{array}$ \\
\hline C2* High Opacity & $\begin{array}{l}-9.69 * * * \\
(-2.78)\end{array}$ & $\begin{array}{l}-10.85^{* * *} \\
(-3.19)\end{array}$ & $\begin{array}{l}-12.41 * * * \\
(-3.90)\end{array}$ \\
\hline C3* High Opacity & $\begin{array}{l}-0.48 \\
(-0.15)\end{array}$ & $\begin{array}{l}-1.30 \\
(-0.33)\end{array}$ & $\begin{array}{l}-3.23 \\
(-1.03)\end{array}$ \\
\hline $\mathrm{C} 1 * \mathrm{FACT}$ & $\begin{array}{l}-4.68 \\
(-0.93)\end{array}$ & $\begin{array}{l}1.20 \\
(0.24)\end{array}$ & $\begin{array}{l}2.82 \\
(0.91)\end{array}$ \\
\hline $\mathrm{C} 2 * \mathrm{FACT}$ & $\begin{array}{l}-12.48 * * * \\
(-2.85)\end{array}$ & $\begin{array}{l}-3.43 \\
(-0.79)\end{array}$ & $\begin{array}{l}-1.54 \\
(-0.35)\end{array}$ \\
\hline $\mathrm{C} 3 * \mathrm{FACT}$ & $\begin{array}{l}-7.76 * * \\
(-1.97)\end{array}$ & $\begin{array}{l}-4.68 \\
(-0.98)\end{array}$ & $\begin{array}{l}0.17 \\
(0.04)\end{array}$ \\
\hline C1* High Opacity *FACT & $\begin{array}{l}-9.90^{*} \\
(-1.94)\end{array}$ & $\begin{array}{l}4.88 \\
(0.89)\end{array}$ & $\begin{array}{l}-1.92 \\
(-0.53)\end{array}$ \\
\hline C2* High Opacity *FACT & $\begin{array}{l}3.42 \\
(0.68)\end{array}$ & $\begin{array}{l}7.04 \\
(1.39)\end{array}$ & $\begin{array}{l}9.00 * \\
(1.71)\end{array}$ \\
\hline C3* High Opacity *FACT & $\begin{array}{l}-2.69 \\
(-0.57)\end{array}$ & $\begin{array}{l}0.12 \\
(0.02)\end{array}$ & $\begin{array}{l}4.90 \\
(1.10)\end{array}$ \\
\hline Year Fixed Effects & Yes & Yes & Yes \\
\hline Control variables & Yes & Yes & Yes \\
\hline No. Obs. & 1,150 & 1,150 & 1,150 \\
\hline No. Banks & 330 & 330 & 330 \\
\hline
\end{tabular}

Variable definitions: Dependent variable is DP (dividend payouts) $=$ cash dividend related to the period/earnings. High Opacity= dummy variable equals one if the opacity composite index is higher than the sample median. FACT: High Protect = dummy variable equals one if the index for degree of minority shareholder protection is higher than the sample median; Strong Supervisory=dummy variable equals one if the supervisory regime index is higher than the sample median; Crisis=dummy variable equals one during the financial crisis period 2007 2012. $z$-statistics are in parentheses, with $p<0.1^{*}, p<0.05^{* *}$ and $p<0.01 * * *$. Standard error is adjusted for clustering on bank. 
Table 8. Wald tests for differences in dividend payout ratios for high vs. low opacity and for different levels of shareholder protection (computed from Table 7).

\begin{tabular}{|c|c|c|c|c|c|}
\hline & & & \multicolumn{2}{|c|}{ Opacity } & \multirow{2}{*}{$\begin{array}{c}\text { Difference in } \\
\text { Coefficient } \\
\text { High }- \text { Low Opacity (a) }\end{array}$} \\
\hline & & & Low & High & \\
\hline \multirow{6}{*}{ Protect } & \multirow{3}{*}{ Low } & $\mathrm{C} 1$ & $32.32 * * *$ & $32.34 * * *$ & 0.02 \\
\hline & & $\mathrm{C} 2$ & $43.97 * * *$ & $34.28 * * *$ & $-9.69 * * *$ \\
\hline & & $\mathrm{C} 3$ & $43.91 * * *$ & $43.43 * * *$ & -0.48 \\
\hline & \multirow{3}{*}{ High } & $\mathrm{C} 1$ & $27.64 * * *$ & $17.76^{* *}$ & $-9.88 * * *$ \\
\hline & & $\mathrm{C} 2$ & $31.49 * * *$ & $25.22 * * *$ & -6.27 \\
\hline & & $\mathrm{C} 3$ & $36.15 * * *$ & $32.98 * * *$ & -3.17 \\
\hline \multirow{3}{*}{\multicolumn{2}{|c|}{$\begin{array}{l}\text { Difference in Coefficient } \\
\text { High - Low Protect (b) }\end{array}$}} & \multicolumn{2}{|c|}{$-14.58 * * *$} & \multicolumn{2}{|l|}{-14.58 *** } \\
\hline & & & -12.48 *** & $-9.06^{* *}$ & \\
\hline & & & $-7.76 * *$ & $-10.45^{* * *}$ & \\
\hline
\end{tabular}

$\mathrm{p}<0.1 *, \mathrm{p}<0.05^{* *}$ and $\mathrm{p}<0.01 * * *$

Variable definitions: The opacity measure is the opacity composite index (Opacity); Protect is the level of shareholder protection. The number in the Table is sum of coefficients from Equation (2), depending on each cluster, the degree of opacity, and the level of shareholder protection.

Table 9. Wald tests for differences in dividend payout ratios for high vs. low opacity and for different levels of supervisory strength (computed from table 7).

\begin{tabular}{|c|c|c|c|c|c|}
\hline & & & \multicolumn{2}{|c|}{ Opacity } & \multirow{2}{*}{$\begin{array}{c}\text { Difference in } \\
\text { Coefficient } \\
\text { High }- \text { Low Opacity (a) }\end{array}$} \\
\hline & & & Low & High & \\
\hline \multirow{6}{*}{ Supervisory } & \multirow{3}{*}{ Weak } & $\mathrm{C} 1$ & $27.72 * * *$ & $19.43^{* * *}$ & $-8.29 * *$ \\
\hline & & $\mathrm{C} 2$ & $37.92 * * *$ & $27.07 * * *$ & $-10.85^{* * *}$ \\
\hline & & $\mathrm{C} 3$ & $40.55^{* * *}$ & $39.25^{* * *}$ & -1.3 \\
\hline & \multirow{3}{*}{ Strong } & $\mathrm{C} 1$ & $28.92 * * *$ & $25.51 * * *$ & -3.41 \\
\hline & & $\mathrm{C} 2$ & $34.49 * * *$ & $30.68 * * *$ & -3.81 \\
\hline & & $\mathrm{C} 3$ & $35.87 * * *$ & $34.69 * * *$ & -1.18 \\
\hline \multirow{3}{*}{$\begin{array}{l}\text { Difference in Coefficient } \\
\text { High - Low Protect (b) }\end{array}$} & & $\mathrm{C} 1$ & 1.2 & 6.08 & \\
\hline & & $\mathrm{C} 2$ & -3.43 & 3.61 & \\
\hline & & $\mathrm{C} 3$ & -4.68 & -4.56 & \\
\hline
\end{tabular}

$\mathrm{p}<0.1^{*}, \mathrm{p}<0.05^{* *}$ and $\mathrm{p}<0.01 * * *$

Variable definitions: The opacity measure is the opacity composite index (Opacity); Supervisory is the level of the supervisory regime index. The number in the Table is sum of coefficients from Equation (2), depending on each cluster, the degree of opacity, and the strength of supervisory regimes. 
Table 10. Wald tests for differences in dividend payout for high vs. low opacity in crisis and non crisis time (computed from table 7).

\begin{tabular}{|c|c|c|c|c|c|}
\hline & & & \multicolumn{2}{|l|}{ Opacity } & Difference in Coefficient \\
\hline & & & Low & High & High - Low Opacity (a) \\
\hline \multirow{6}{*}{ Crisis } & \multirow{3}{*}{ No } & $\mathrm{C} 1$ & $34.93 * * *$ & $26.49 * * *$ & $-8.44^{*}$ \\
\hline & & $\mathrm{C} 2$ & $44.41 * * *$ & $29.80 * * *$ & $-14.60 * * *$ \\
\hline & & $\mathrm{C} 3$ & $42.56^{* * *}$ & $39.36 * * *$ & -2.7 \\
\hline & \multirow{3}{*}{ Yes } & $\mathrm{C} 1$ & $28.79 * * *$ & $23.82 * * *$ & $-4.96^{*}$ \\
\hline & & $\mathrm{C} 2$ & $36.27 * * *$ & $28.88 * * *$ & $-7.39 * *$ \\
\hline & & $\mathrm{C} 3$ & $37.27 * * *$ & $35.60 * * *$ & -1.67 \\
\hline Difference in Coefficient & & $\mathrm{C} 1$ & -6.14 & -2.67 & \\
\hline \multirow[t]{2}{*}{ Crisis - no crisis (b) } & & $\mathrm{C} 2$ & -8.13 & -0.92 & \\
\hline & & $\mathrm{C} 3$ & -5.29 & -4.26 & \\
\hline
\end{tabular}

$\mathrm{p}<0.1 *, \mathrm{p}<0.05^{* *}$ and $\mathrm{p}<0.01 * * *$

Variable definitions: The opacity measure is the opacity composite index (Opacity); Crisis is the dummy variable that takes the value of one in 2007-2012 and zero otherwise. The number in the Table is sum of coefficients from Equation (2), depending on each cluster, the degree of opacity, and the economic condition. 


\section{Appendix 1}

Table A1. Correlation matrix of opacity measures

\begin{tabular}{llllll} 
Variables & Opacity & EM & EF & MF & Loan \\
\hline Opacity & 1.000 & & & & \\
EM & $0.285^{*}$ & 1.000 & & & \\
EF & $0.343^{*}$ & 0.056 & 1.000 & & \\
MF & $-0.380^{*}$ & $-0.135^{*}$ & -0.049 & 1.000 & \\
Loan & $0.373^{*}$ & 0.052 & $-0.092^{*}$ & $0.301^{*}$ & 1.000
\end{tabular}

Variable definitions: Opacity = composite index of opacity measures (EM, EF, MF and Loan); $E M=$ earnings management; $E F=$ earnings forecast error; $M F=$ the negative value of (long term + short term market funding)/total assets; Loan $=$ net loans/total assets. With $p<0.05 *$. 
Table A2. Correlation Matrix

\begin{tabular}{|c|c|c|c|c|c|c|c|c|c|c|c|c|c|c|c|}
\hline & 1 & 2 & 3 & 4 & 5 & 6 & 7 & 8 & 9 & 10 & 11 & 12 & 13 & 14 & 15 \\
\hline $1 \mathrm{C} 1$ & 1.000 & & & & & & & & & & & & & & \\
\hline $2 \mathrm{C} 2$ & $-0.349^{*}$ & 1.000 & & & & & & & & & & & & & \\
\hline $3 \mathrm{C} 3$ & $-0.553^{*}$ & $-0.575^{*}$ & 1.000 & & & & & & & & & & & & \\
\hline 4 Opacity & $-0.079 *$ & $0.077 *$ & -0.002 & 1.000 & & & & & & & & & & & \\
\hline 5 Protect & $0.142 *$ & $-0.206^{*}$ & 0.047 & $0.107 *$ & 1.000 & & & & & & & & & & \\
\hline 6 Supervisory & 0.050 & $-0.243^{*}$ & $0.159 *$ & 0.035 & $0.600 *$ & 1.000 & & & & & & & & & \\
\hline $7 \mathrm{ROA}$ & 0.005 & -0.054 & 0.048 & $0.489 *$ & $0.109 *$ & $0.063^{*}$ & 1.000 & & & & & & & & \\
\hline 8 Assets growth & $0.086^{*}$ & 0.001 & $-0.079 *$ & $0.092 *$ & $0.091^{*}$ & $0.092 *$ & $0.120^{*}$ & 1.000 & & & & & & & \\
\hline 9 Size & $0.145^{*}$ & $-0.129 *$ & -0.016 & $-0.473 *$ & $-0.060 *$ & $0.058^{*}$ & $-0.342^{*}$ & -0.023 & 1.000 & & & & & & \\
\hline $10 \mathrm{M} \& \mathrm{~A}$ & $0.175^{*}$ & -0.014 & $-0.136^{*}$ & $-0.174 *$ & 0.024 & $0.082 *$ & -0.037 & $0.078^{*}$ & $0.356^{*}$ & 1.000 & & & & & \\
\hline 11 Ln Z Score & -0.010 & 0.052 & -0.032 & 0.005 & -0.013 & -0.008 & $0.056^{*}$ & 0.008 & $-0.112 *$ & -0.008 & 1.000 & & & & \\
\hline 12 High Capitalized & $-0.287^{*}$ & -0.014 & $0.262 *$ & $0.193 *$ & $0.182 *$ & $0.133^{*}$ & $0.130 *$ & $-0.137^{*}$ & $-0.362^{*}$ & $-0.164 *$ & -0.045 & 1.000 & & & \\
\hline 13 High Charter & $-0.106^{*}$ & -0.045 & $0.128^{*}$ & $0.344 *$ & $0.089 *$ & -0.000 & $0.229 *$ & -0.022 & $-0.480^{*}$ & $-0.164 *$ & -0.002 & $0.288^{*}$ & 1.000 & & \\
\hline 14 Distress & 0.055 & -0.017 & -0.032 & $-0.086 *$ & $-0.073^{*}$ & -0.029 & $-0.065^{*}$ & -0.036 & $0.103^{*}$ & $0.132^{*}$ & $-0.091 *$ & $-0.063 *$ & -0.021 & 1.000 & \\
\hline 15 GDP growth & 0.016 & $-0.074 *$ & $0.058^{*}$ & $0.059 *$ & $0.182 *$ & $0.134 *$ & $0.173 *$ & $0.179 *$ & -0.027 & 0.006 & $0.076^{*}$ & 0.012 & -0.013 & $-0.105^{*}$ & 1.000 \\
\hline $\begin{array}{l}\text { Variable definitions: } \\
\text { Rule of Law index mult } \\
\text { Size }=\text { log of total as } \\
\text { Capitalized = dummy } \\
\text { customer deposits to to }\end{array}$ & $\begin{array}{l}-C 3=\text { clus } \\
\text { ied by rev } \\
\text { ts; } M \& A \\
\text { riables eq } \\
\text { l assets is }\end{array}$ & $\begin{array}{l}\text { ers dummy } \\
\text { ed Anti Di } \\
\text { dummy vo } \\
\text { als one ift } \\
\text { arger than }\end{array}$ & $\begin{array}{l}\text { ariables; } \\
\text { ctor indes } \\
\text { iable equ } \\
\text { bank rish } \\
\text { he sample }\end{array}$ & acity $=c o$ & posite ind & ofopacit & measures ( & $\begin{array}{l}\text { cial inst } \\
\text { eriod is } \\
\text { one if ba }\end{array}$ & $\begin{array}{l}\text { ions; Ln } \\
\text { er than }\end{array}$ & $\begin{array}{l}\text { Protect }= \\
\text { OA }=\text { Retu } \\
\text { core }=\text { lo } \\
\text { ple media } \\
\text { sed; GDP }\end{array}$ & $\begin{array}{l}\text { dex of deg } \\
\text { non Asset } \\
\text { of } z \text { score } \\
\text { High Ch } \\
\text { rowth }=a \text { a }\end{array}$ & $\begin{array}{l}\text { e of minor } \\
\text { Assets gro } \\
\text { calculated } \\
\text { ter }=\text { dumı } \\
\text { ual GDP g }\end{array}$ & $\begin{array}{l}\text { y shareho } \\
\text { th = ann } \\
\text { pver } 3-y e \\
\text { y variable }\end{array}$ & $\begin{array}{l}\text { ers protect } \\
\text { lgrowth o. } \\
\text { rolling wt } \\
\text { quals one } \\
5 * \text {. }\end{array}$ & $\begin{array}{l}\text { n, whic } \\
\text { total ass } \\
\text { dows; } H \\
\text { the ratic }\end{array}$ \\
\hline
\end{tabular}


Table A3. Ownership type and dividend payout of European commercial banks for the period 20042012

Dependent: DP

Bank $5.52 * * *$

$$
\text { (2.91) }
$$

Institutional

Industrial

$$
-5.47 * * *
$$

State

$$
\text { (-0.75) }
$$

Individual/Family

Others

\begin{tabular}{|c|c|c|c|c|c|c|}
\hline High Opacity & $\begin{array}{l}-2.30 * * * \\
(-3.07)\end{array}$ & $\begin{array}{l}-2.36 * * * \\
(-3.16)\end{array}$ & $\begin{array}{l}-2.28 * * * \\
(-3.05)\end{array}$ & $\begin{array}{l}-2.33 * * * \\
(-3.13)\end{array}$ & $\begin{array}{l}-2.34 * * * \\
(-3.13)\end{array}$ & $\begin{array}{l}-2.34 * * * \\
(-3.15)\end{array}$ \\
\hline High Protect & $\begin{array}{l}-3.35 * * * \\
(-6.93)\end{array}$ & $\begin{array}{l}-3.55^{* * *} \\
(-7.20)\end{array}$ & $\begin{array}{l}-3.51 * * * \\
(-7.23)\end{array}$ & $\begin{array}{l}-3.58 * * * \\
(-7.29)\end{array}$ & $\begin{array}{l}-3.50 * * * \\
(-7.18)\end{array}$ & $\begin{array}{l}-3.57 * * * \\
(-7.25)\end{array}$ \\
\hline Constant & $\begin{array}{l}69.75^{* * * *} \\
(7.22)\end{array}$ & $\begin{array}{l}74.24 * * * \\
(7.79)\end{array}$ & $\begin{array}{l}73.71 * * * \\
(7.75)\end{array}$ & $\begin{array}{l}73.65^{* * * *} \\
(7.74)\end{array}$ & $\begin{array}{l}74.63 * * * \\
(7.82)\end{array}$ & $\begin{array}{l}73.92 * * * \\
(7.78)\end{array}$ \\
\hline Controls & Yes & Yes & Yes & Yes & Yes & Yes \\
\hline Year Fixed Effects & Yes & Yes & Yes & Yes & Yes & Yes \\
\hline No. Observation & 1,150 & 1,150 & 1,150 & 1,150 & 1,150 & 1,150 \\
\hline No. Bank & 330 & 330 & 330 & 330 & 330 & 330 \\
\hline R-squared (overall) & 0.15 & 0.12 & 0.14 & 0.13 & 0.13 & 0.12 \\
\hline
\end{tabular}




\section{Appendix 2}

\section{Estimation of an earnings prediction model}

The capacity of investors to forecast the profitability of a firm relies on the information they have. We assume that the rational prediction of stock markets may be captured by the prediction of a well-specified regression model based on publicly available information. Under this assumption, a positive residual of the regression means that stock markets underestimated banks' earnings. In this case, the actual earning turns out to be larger than the ones predicted by the stock market model. On the contrary, the residual of regression is negative when the earning predicted by the stock market is larger than the actual earning. In both cases, publicly available information do not permit to perfectly forecast the profitability. We follow Park (1999) and Crouzille et al. (2004) by considering that the residual of an earnings prediction model can be used as a proxy to measure banks private information. We build on an empirical specification that is close to those in Crouzille et al. (2004), that we augment with other explanatory variables following Dietrich and Wanzenried (2014):

$$
\begin{aligned}
\text { ROA }_{i j, t}=\alpha_{0} & +\beta_{1} \text { ROA }_{i j, t-1}+\beta_{2} \text { Expenses }_{i j, t-1}+\beta_{3} \text { Deposit }_{i j, t-1}+\beta_{4} \text { ET }_{i j, t-1} \\
& +\beta_{5} \text { Loan }_{i j, t-1}+\beta_{6} \text { NII }_{i j, t-1} \\
& +\beta_{7} \text { Cost of Fund }_{i j, t-1}+\beta_{8} \text { Dispersion }_{i j, t-1} \\
& +\beta_{9} \text { Bank Concentration }_{j, t-1}+\beta_{10} \text { ROAI }_{j, t-1} \\
& +\beta_{11} \text { GDPgrowth }_{j, t-1}+\varepsilon_{i, t+1}
\end{aligned}
$$

where $R O A_{i j, t}$ is the return on asset of bank $i$ at time $t$. Expenses is operating expense to operating profit that reflects operational efficiency; Deposit $t_{i j, t-1}$ is customer deposit divided by total assets; $E T A_{i j, t-1}$ is the ratio of equity to total assets measuring bank liquidity and leverage; Loan $_{i j, t-1}$ is the ratio of net loan to total assets; $N I I_{i j, t-1}$ is the ratio of non-interest income to total income, measuring income diversification; Cost of Fund $_{i, t}$ is the ratio of interest expenses over total deposits; Dispersion $_{i j, t-1}$ is a measure of ownership dispersion; Bank Concentration ${ }_{j, t-1}$ is the Herfindahl-Hirschman Index of total assets for each year on each country; $R O A I_{j, t-1}$ is the average ROA of the banking Industry for the whole country for each year; GDPgrowth grt $1_{1}$ is the growth rate of gross domestic product of each country.

We perform the estimation each year using OLS and we use the absolute value of the residual from the regression estimations to generate our measurement for bank opacity $E F$. The asymmetric information between insiders and outsiders should be relatively high for a bank $i$ when the absolute value of residual of the regression $\varepsilon_{i}$ is relatively high.

\section{Degree of earnings management}

We build on an empirical panel specification that is close to those in Greenawalt and Sinkey (1988), Bikker and Metzemakers (2005), Anandarajan et al. (2007) and Bouvatier et al. (2014) to measure the degree of earning management: 


$$
\begin{aligned}
L L P_{i j, t}=\alpha_{0}+ & \beta_{1} L L P_{i j, t-1}+\beta_{2} \operatorname{Loan}_{i j, t}+\beta_{3} N L \text { growth }_{i j, t}+\beta_{4} G D P \text { growth }_{j, t} \\
& +\beta_{5} \operatorname{COM}_{i j, t}+\beta_{6} E R_{i j, t}+\beta_{7} \operatorname{SIGN}_{i j, t}+\beta_{8} E T A_{i j, t-1}+\alpha_{t} \\
& +\varepsilon_{i j, t}
\end{aligned}
$$

where $L L P_{\mathrm{ij}, \mathrm{t}}$ is the ratio of loan loss provision to total assets.

The non-discretionary component represents loan loss provisions made to cover expected credit losses. In our specification it is identified by $L_{o a n}{ }_{i j, t}$ the ratio of net loan to total assets, $N L$ growth $_{i j, t}$ the net loan growth, $C O M_{i j, t}$ the ratio of commission and fee income to total assets and GDPgrowth ${ }_{j t}$ the growth rate of gross domestic product. The earnings management results from two different management objectives. Banks can use their loan loss provisions (LLP) to smooth their income; banks understate (overstate) LLP when earnings are expected to be low (high) relative to that of other years (inter-temporal smoothing). If banks use LLP to smooth earnings, then we would expect a significantly positive relation between earnings before taxes and loan loss provisions $E R / T A_{i j, t}$ and LLP. Banks can also use LLP to signal their financial strength. If signaling is an important incentive in choosing LLP, then we should observe a significantly positive relation between LLP and changes in future earnings before taxes and LLP, with $S I G N_{i j, t}$ defined as $\left(\left(E R_{i t+1}-E R_{i t}\right) / 0.5\left(T A_{i, t}+T A_{i, t+1}\right)\right)$. We also control for a possible capital management behavior, even if scope for such behavior is more limited since Basel 1 and even more so under Basel 2. Banks with low regulatory capital could be more inclined to make loan loss provisions to keep their capital ratio adequate. To control for such behavior, we include the lagged ratio of equity to total assets (ETA $i j, t-1)$.

We use GMM system estimation to estimate Equation (A2) with forward orthogonal deviations transformation of the original equation as suggested by Arellano and Bover (1995) and the two-step estimator including the Windmeijer (2005) finite-sample correction. We only instrument the lagged dependent variable and assuming the other explanatory variables are strictly exogenous.

Our results show that European commercial banks use their LLP to smooth their earnings and signal their financial strength. We then compute our earning management variable $(E M)$ as follows: $E M_{i j, t}=\beta_{6} E R_{i j, t}+\beta_{7} S I G N_{i j, t}$. 